\title{
ADAPTASI MODEL PEMBELAJARAN TUTORIAL ONLINE UT PADA MASA PEMBELAJARAN DARURAT COVID-19
}

\author{
Athiyah Salwa \\ Universitas Sains dan Teknologi Komputer Semarang Jawa Tengah, Indonesia \\ Email: athiyah@stekom.ac.id
}

Received: 2020-02-15; Accepted: 2020-03-05; Published: 2020-03-15

\begin{abstract}
Abstrak
Pandemi yang disebabkan oleh wabah Covid-19 telah mengubah banyak hal dalam proses belajar mengajar di Indonesia. Hal ini terjadi karena sebagian besar proses belajar mengajar di negeri ini masih dilakasanakan dengan model konvensional dimana pembelajaran sebagai proses tranfer ilmu pengetahuan hanya berasal dari guru, buku teks, dan papan tulis sebagai sumber utama dan kolaborasi ini hanya terjadi di ruang-ruang kelas. Di masa Pandemi, Pemerintah telah menetapkan keputusan bahwa kegiatan pendidikan harus dilaksanakan secara daring. Sekolah-sekolah dilarang melaksanakan kegiatan pembelajaran tatap muka untuk menghindari penularan yang disebabkan oleh wabah. Hal ini membuat pemangku kebijakan di sektor pendidikan mencari sistem dan strategi pembelajaran yang sesuai dengan kondisi mereka. Universitas Terbuka yang merupakan pelopor pembelajaran jarak jauh memiliki satu program yang dapat memfasilitasi mahasiswa dari seluruh penjuru negeri untuk belajar. Tutorial Online yang diselenggarakan oleh Universitas Terbuka ini memungkinkan mahasiswa untuk mengakses materi tidak hanya dari buku teks pokok, tetapi juga dari video pembelajaran yang dibuat oleh tutor, latihan, tugas, dan bahkan menjembatani komunikasi dengan tutor dalam bentuk pesan. Fitur-fitur ini sangat tepat dan cocok jika digunakan pada masa pembelajara darurat Covid-19 ini dimana semua kegiatan pendidikan harus dilaksanakan secara daring. Artikel ini mendeskripsikan bagaimana tutorial online UT diimplementasikan untuk menggantikan fungsi pembelajaran konensional menjadi solusi pembelajaran di masa Pandemi Covid-19 untuk mencapai target pembelajaran.
\end{abstract}

Kata Kunci: Pembelajaran Jarak Jauh (PJJ); pembelajaran daring; pembelajaran di masa pandemi

\begin{abstract}
The Covid-19 outbreak today changes a lot in the way teaching and learning progress in Indonesia. In most parts of the country, teachers still use the traditional ways to transfer knowledge from the collaboration of the conventional means of learning such as textbooks, boards, and situated in a classroom. In this pandemic situation, Government proposes that all teaching and learning activities in the schools should be conducted online. It makes stakeholders of education sectors, especially primary and secondary, manage learning strategies and systems. Based on the situation, Universitas Terbuka as the pioneer of open learning system has one program to facilitate students come from different places all around. It has an online tutorial where students can access material not only from the textbook but also supplementary materials such as teacher's tutorial video, online tasks and exercises, and also online assessment. This kind of system can be adapted for traditional schools in the Pandemic era so that learning loss will not happen since students and teachers can still get connected to achieve learning goals. This article describes how the online tutorial UT can be implemented for primary, secondary, and even higher education in the Pandemic era to replace the traditional learning systems.
\end{abstract}

Keywords : distance learning; teaching and learning in the pandemic era; asynchronous and synchronous learning 


\section{PENDAHULUAN}

Pandemi Covid-19 yang pertama kali muncul di Kota Wuhan, Tiongkok dan menyebar hingga ke seluruh belahan bumi telah mengubah segalanya. Tak terkecuali, kasus wabah virus Corona ini juga muncul dan diumumkan secara resmi pada tanggal 2 Maret 2020, meskipun para ahli berpendapat bahwa ada kemungkinan wabah ini sudah masuk ke Indonesia pada bulan Januari 2020 (Ellyvon Prianata, 2020). Tidak hanya mengancam sektor kesehatan saja, wabah ini telah benar-benar mengubah hampir semua sektor baik secara mikro maupun makro. Beberapa sektor kehidupan yang sangat terdampak oleh munculnya wabah ini antara lain kesehatan, ekonomi, sosial budaya, dan pendidikan (Jawahir Gustav Rizal, 2020).

Sejak munculnya wabah ini, Pemerintah telah mengeluarkan keputusan untuk menekan laju penyebaran virus diantaranya adalah dengan menjaga jarak, menghindari kerumunan, dan mengurangi mobilitas (ILMAR \& SH, 2020). Keputusan ini tentunya berdampak besar bagi dunia Pendidikan dimana secara konvensional proses pembelajaran ini melibatkan kegiatan bertatap muka antara pengajar dan pebelajar. Selain itu, kegiatan pendidikan yang berjalan di sekolah-sekolah pada umumnya akan menimbulkan kerumunan baik kegiatan intra, ekstra, maupun kokulikuler. Hal inilah yang menjadi dasar bagi Pemerintah untuk meniadakan kegiatan tatap muka dan mengimbau agar proses pembelajaran dilakukan dalam jaringan (daring). Meskipun bukan hal yang baru dalam dunia Pendidikan, namun bagi sebagian besar sekolah-sekolah di Indonesia, sistem pembelajaran daring meruapakan model pembelajaran yang benar-benar baru khususnya untuk sekolahsekolah di tingkat pendidikan dasar dan menengah. Proses transfer ilmu pengetahuan ini secara umum dilakukan secara tradisional dengan guru, buku teks, papan tulis dan layar merupakan sumber belajar utama. Bagi banyak guru di tingkat pendidikan dasar, penggunaan teknologi dalam proses pembelajaran baik itu sebagai alat ataupun media sangat jarang dilakukan. Untuk itu, pembelajaran daring (online) ini adalah tantangan terbesar yang muncul bersamaan dengan wabah Covid-19 di Indonesia dalam hal ini guru harus tetap melakukan fungsinya sebagai fasilitator pada proses pembelajaran namun peserta didik tidak berapa dalam ruang yang sama dengan guru tersebut.(Astini, 2020)

Proses pembelajaran tersebut sebenarnya telah dilakukan jauh sebelum wabah virus Corona muncul di Indonesia. Proses pembelajaran dalam jaringan memiliki prinsip yang sama dengan Pembelajaran Jarak Jauh (PJJ). Pembelajaran jarak jauh menjadi solusi untuk mengatasi kesulitan dalam melaksanakan pembelajaran secara tatap muka langsung (Herliandry, Nurhasanah, Suban, \& Kuswanto, 2020). Dalam hal ini semua elemen pendidikan, guru, peserta didik, dan juga pemangku kebijakan dipaksa untuk siap melakukan migrasi bersar-besaran dari model pembelajaran konvensional kedalam metode pembelajaran online. Tanpa ada pemberitahuan, sosialisasi, ataupun pelatihan-pelatihan singkat, guru dan perserta didik dituntut untuk bisa dan siap mengimplementasikan dan berpindah dari model pembelajaran luring ke daring. Hal ini tentu terjadi hampir di seluruh belahan bumi yang terdampak wabah Covid-19. Tsunami pembelajaran online telah terjadi hampir diseluruh dunia selama pandemi COVID-19 (Herliandry et al., 2020) PJJ sebagai alternatif pembelajaran di masa Pandemi diterapkan oleh hampir semua tingkat pendidikan yaitu Pendidikan dasar, menengah, dan pendidikan tinggi (Abidin, Hudaya, \& Anjani, 2020)

Model pembelajaran PJJ ini merupakan prinsip yang diusung oleh Universitas Terbuka, satu-satunya universitas yang menyelenggarakan model pendidikan jarak jauh dan terbuka di Indonesia. UT merupakan prototipe ideal bagi perguruan tinggi dan lembagalembaga pendidikan di Indonesia dalam penerapan konsep e-learning(Rahmat, Seminar, \& Suroso, 2019). Istilah pembelajaran jarak jauh dan terbuka yang digunakan di UT adalah 
pembelajaran dilakukan dengan menggunakan media baik cetak yakni modul sebagai sumber belajar utama yang diterbitkan secara mandiri oleh kampus, dan juga media noncetak seperti audio visual, interneta, siaran radio dan televisi. Selain itu, model pembelajaran terbuka adalah dengan tidak adanya batasan usia, masa belajar, waktu registrasi, dan jangka waktu pembelajaran.

Sebagai pelopor e-learning dengan sumber daya dan sebaran layanan yang luas, UT dituntut untuk selalu dapat menyediakan sistem teknologi informasi yang memadai terlebih untuk menjangkau wilayah Indonesia yang sangat luas (Rahmat et al., 2019) Untuk memberikan tambahan fasilitas belajar bagi mahasiswa, UT juga memiliki program yang disebut dengan tutorial online (secara lengkap akan dibahas dalam sub-bab selanjutnya). Secara singkat, tutorial online ini merupakan wadah yang memberikan media belajar tambahan selain Buku Materi Pokok (BMP) yang dapat diakses oleh mahasiswa untuk memperdalam pemahaman terhadap sebuah materi yang dapat diakses kapanpun dan dimanapun. Selama ini sistem pembelajaran sekolah-sekolah formal berlawanan dengan prinsip yang diterapkan di UT dimana batasan waktu belajar peserta didik ditentukan oleh sekolah dengan batasan waktu jam dan ruang. Inilah masalah besar yang dihadapi oleh sekolah-sekolah di masa Pandemi saat ini. Untuk itu, sistem pembelajaran pada tutorial online inilah yang dapat diterapkan di sekolah-sekolah saat ini. Dengan mengadaptasi sistem tutorial online sebagai pengganti model pembelajaran tatap muka, guru dapat memberikan materi dan melakukan kegiatan pengajaran kepada peserta didik. Model pembelajaran ini tentu lebih fleksibel karena peserta didik dapat mengakses materi tidak terbatas pada waktu dan tempat. Artikel ini mencoba menggambarkan dan memberikan gagasan baru tentang sistem pembelajaran dalam jaringan atau PJJ yang dapat diaplikasikan oleh pemangku kebijakan penyelenggara Pendidikan dalam pembelajaran darurat di masa Pandemi.

\section{METODE PENELITIAN}

Penelitian ini menggunakan metode deskritif kualitatif dimana hasil dan pembahasan dalam penelitian akan disajikan dalam bentuk gambar dan huruf. Penelitian ini akan mendeskripsikan model PJJ yang digunakan Pendidikan tinggi yaitu Politeknik IImu Pelayaran Semarang (PIP). Pada bagian pembahasan, akan digambarkan penggunaan model PJJ yang merupakan adaptasi dari model PJJ yang digunakan UT dalam tutorial online. Teknik pengumpulan data dilakukan melalui wawancara dan observasi yang mendalam dengan key informan dan dilakukan selama satu semester yaitu pada semester genap tahun pelajaran 2020/2021 atau pada kisaran bulan Januari-Juni 2021. Pada waktu tersebut, wabah covid-19 masih melanda selama kuranng lebih satu tahun di Indonesia dan proses pembelajaran PJJ sudah cukup stabil dilakukan di setiap institusi. Artinya, proses PJJ sudah berlangsung dalam kurun waktu satu tahun pelajaran. Teknik pengumpulan data dilakukan dengan menggunakan wawancara, observasi, dan dokumentasi.(Moleong, 2007)

\section{HASIL PENELITIAN DAN PEMBAHASAN}

1. Pembelajaran Jarak Jauh di Perguruan Tinggi

Adaptasi praktik Pembelajaran Jarak Jauh di tingkat Pendidikan Tinggi yang akan dibahas dalam penelitian ini adalah PJJ di Perguruan Tinggi Vokasi di Kota Semarang. Perguruan tinggi yang menjadi objek pertama dalam penelitian ini adalah Politeknik IImu Pelayaran Semarang. Politeknik ini menyelenggarakan pendidikan bagi mahasiswa di bidang pelayaran namun bukan merupakan perguruan tinggi ikatan dinas sehingga 
mahasiswa berhak menentukan dimana mereka akan bekerja nantinya setelah lulus/ wisuda. Politeknik IImu Pelayaran (PIP) Semarang adalah pendidikan tinggi negeri milik Kementerian Perhubungan Republik Indonesia yang berdiri pada tahun 1951 dan telah masuk White List di International Maritime Organization tahun 2000. PIP Semarang mencetak lulusan siswa-siswi sekolah menengah atas menjadi Perwira Pelayaran Besar dan Tenaga Ahli Angkutan Laut/Kepelabuhanan guna memenuhi kebutuhan armada angkutan laut nasional maupun internasional.

Perguruan tinggi ini menyelenggarakan pendidikan untuk mencetak lulusan dengan gelar Diploma IV atau setingkat dengan Sarjana (S1). Selama masa pendidikannya mahasiswa yang disebut dengan taruna-taruni diwajibkan untuk tinggal di asrama selama dua tahuan yaitu pada semester satu hingga semester empat. Memasuki semester 5, taruna-taruni melaksanakan Praktik Laut ataupun Praktik Darat selama satu tahun. Pada tahun tersebut, mahasiswa tidak lagi tinggal di asrama dan menjalani praktik kerja lapangan sebagaimana yang dilakukan oleh mahasiwa di perguruan tinggi lainnya. Di tahun terakhirnya, pada semester 7-8 taruna-taruni mulai menyusun laporan akhir (skripsi) dan umumnya mahasiswa lulus dan diwisuda pada semester 8. Di tahun terakhirnya para taruna tidak lagi tinggal di asrama. Taruna-taruni diperbolehkan untuk tinggal di luar kampus, dan datang ke kampus pada saat pembelajaran berlangsung.

Adanya Pandemi yang melanda selama lebih dari satu tahun, membuat sistem pendidikan yang diterapkan di PIP berubah. Jika pada tahun pertamanya, taruna-taruni diwajibkan untuk menjalani masa pendidikan di asrama yang berada satu lokasi dengan kampus, pada tahun pelajaran 2020/2021, taruna taruni menjalani masa pendidikan dari rumah. Model pembelajaran secara penuh dilaksanakan secara online atau PJJ. Pada tahun pelajaran sebelumnya, di pertengahan semester genap 2019/2020, sebenaranya PJJ juga sudah mulai diterapkan pada saat wabah COVID-19 pertama kali muncul di Indonesia. Namun, PJJ yang dilakukan di tahun pelajaran tersebut berbeda dengan tahun pelajaran 2020/2021.

Pada awal munculnya virus Corona bulan Maret 2020, taruna taruni yang masih berada di asrama dipersiapkan untuk tetap tinggal di asrama. Namun, mengingat pengajar dan tenaga kependidikan yang terlibat dalam proses pendidikan berasal dari luar kampus dan untuk meminimalisir adanya risiko penularan, maka sesegera mungkin para taruna harus dipulangkan. Para taruna yang telah dipulangkan kemudian melaksanakan pendidikan dengan sistem PJJ. Karena dimulai di tengah semester, dan sistem PJJ belum dipersiapkan secara matang, platform yang digunakan untuk melaksanakan pembelajaran adalah dengan aplikasi messenger dan video conference. Penggunaan dua aplikasi tersebut untuk memenuhi kebutuhan proses pembelajaran secara sinkronus dan asinkronus. Aplikasi messenger yang digunakan adalah WhatsApp mengingat aplikasi ini mudah digunakan dan hampir setiap orang dapat menggunakannya. Para pengajar menggunakan WA untuk memberikan materi, latihan, dan tugas yang sebagai media pembelajaran tambahan selain virtual meeting yang dilakukan dengan aplikasi video conference. Pembelajaran sinkronus dilakukan dengan menggunaka Google Meet, Zoom, dan Webex sesuai dengan preferensi dari masingmasing pengajar. Karena memang tidak didesain untuk menjembatani pembelajaran seutuhnya, penggunaan WA ini membuat pengelolaan pembelajaran tidak sistematis. Hal ini dikarenakan materi, tugas, latihan, bahkan interaksi antara antara dosen dengan taruna bercampur menjadi satu sehingga menyulitkan untuk melaksanakan proses assessmen ataupun inventarisasi tugas ataupun dokumentasi kegiatan taruna. Untuk itu, 
pada semester selanjutnya, aplikasi e-learning sudah menggunakan laman web berbasis moodle, sama seperti yang digunakan oleh UT pada Tutorial Online.

Pada semester genap 2020/2021, aplikasi e-learning berbasis moodle yang telah didesain untuk melaksanakan PJJ di PIP sudah dapat digunakan. Menggunakan basis yang sama dengan UT, maka materi yang dapat disajikan oleh pengajar dapat disesuaikan dengan kebutuhan tujuan pembelajaran. Perbedaan penggunakan aplikasi e-learning dengan PIP ini adalah, jika di UT seluruh materi, latihan, tugas, dan pengayaan telah diset seragam antara satu kelas dengan kelas lainnya, di PIP seluruh instrumen kelengkapan media pembelajaran didesain sendiri oleh masing-masing pengajar. Saat pertama kali log in ke dalam situs, fitur-fitur yang disajikan masih kosong dan belum berisikan materi yang akan dipelajari. Untuk itu, pengajar harus betul-betul dapat memilih materi pembelajaran yang baik dan menarik agar pelaksanaan PJJ dapat dicapai secara optimal sesuai dengan tujuan pembelajaran yang tercantum dalam RPP.

Aplikasi e-learning yang digunakan pada Tutorial Online UT berisikan materi dan pengayaan yang didesain keseragamannya oleh UT Pusat bukan UPBJJ (Unit Program Belajar Jarak Jauh), mengingat Ujian Akhir Semester yang akan ditempuh oleh mahasiswa UT dari seluruh daerah di Indonesia sama. Pada laman e-learning, tutor sebagai fasilitator tutorial online, wajib menyiapkan video sapaan yang berisikan materi tentang mata kuliah selama 8 minggu. Di setiap minggunya, tutor membahas secara singkat materi yang akan dipelajari dan tenggat waktu pengumpulan tugas atau latihan. Selain video yang berisi ringkasan materi yang akan dibahas dalam satu minggu, materi yang sudah disiapkan merupakan materi pendukung atau materi tambahan dari yang sudah ada di modul. Materi tersebut berasal dari sumber internet dan dibuat dengan atraktif untuk dapat dipahami dengan baik. Materi pembelajaran disertai dengan latihan mandiri yang dapat dikerjakan untuk dapat melatih dan menguji pemahaman mahasiswa. Yang terpenting dari semua itu, terdapat satu buah forum diskusi di setiap minggunya yang memungkinkan adanya interaksi antara mahasiswa. Diskusi ini menjadi penting karena setiap minggu dinilai oleh tutor. Selain itu, diskusi ini juga mengukur apakah mahasiswa sudah paham dengan materi yang diajarkan atau belum dan juga tutor dapat memantau setiap minggu mahasiswa mana saja yang aktif dari awal hingga akhir pembelajaran. Apabila terdapat pertanyaan terkait tentang materi, mahasiswa dapat bertanya di forum diskusi dan mahasiswa lain dapat memberikan jawaban atau solusi tanpa menunggu jawaban dari tutor. Forum diskusi ini sangat penting untuk menggantikan kelas tatap muka. Dalam forum diskusi ini seolah-olah mahasiswa berinteraksi satu sama lain dan juga tutor dapat terlibat didalam diskusi tersebut. Forum diskusi ini bersifat wajib diikuti oleh setiap mahasiswa. Setiap mahasiswa wajib menjadi aktif dalam diskusi tersebut. Inilah yang menjadi keistimewaan dari Tutorial Online. Poin penting terakhir yang ada dalam Tutorial Online UT adalah adanya tugas yang diberikan pada minggu ke-3, ke-5, dan ke-7. Tugas ini memiliki bobot penilaian yang lebih besar dibandingkan dengan nilai diskusi yang ada setiap minggu. Sehingga, pada mingguminggu tersebut mahasiswa wajib mengerjakan tugas dan diskusi. Tugas ini berisikan soal yang dibahas dalam 2 minggu sebelumnya.

Assessmen pada tutorial ini merupakan rangkuman dari keseluruhan aktifitas yang dilakukan oleh mahasiswa diantaranya adalah daftar hadir menyimak materi yang tersedia, menjawab pertanyaan (terlibat aktif dalam forum diskusi), mengerjakan latihan mandiri (penilaian secara otomatis), serta tugas yang diberikan sebanyak tiga kali dalam kurun waktu 8 minggu. Keselurah aktifitas ini semuanya dinilai dan diformulasikan untuk 
memperoleh nilai akhir. Tutor hanya perlu mengunduh rekapan nilai ini dari laman web dengan mudah secara otomatis.

Rangkaian materi, kegiatan dan assessmen yang didesain dalam Tutorial Online UT ini dapat diadaptasi oleh PIP dengan sama persis karena penggunaan basis elearning yang sama. Terlebih, pengajar diberikan keleluasaan untuk mengembangkan materi pembelajaran sendiri. Tentu saja, materi pembelajaran ini harus sesuai dengan tujuan pembelajaran yang disusun di awal. Selain aktifitas PJJ yang disebutkan di atas, PIP juga memberikan kesempatan bagi para pengajar untuk memenuhi kebutuhan pembelajaran secara langsung (sinkronus) dengan menggunakan aplikasi video conference. Pelaksanaan pembelajaran sinkronus ini dibuktikan dengan mencantumkan tautan pertemuaan aplikasi video conference seperti Zoom atau Google Meet. Mengadaptasi aktifitas PJJ Tutorial Online UT, rangkaian aktifitas PJJ pada laman elearning PIP adalah a) link pertemuan virtual; b) materi yang diberikan dalam bentuk slide Power Point, PDF, ataupun gambar; c) latihan pengayaan mandiri yang didapat dari sumber internet yang lain; d) penugasan harian yang diberikan oleh pengajar sebagai penilaian.

2. Kendala Adaptasi PJJ Tutorial Online di Tingkat Pendidikan Tinggi

Beberapa kendala yang ditemukan selama proses pembelajaran menggunakan model PJJ yang sama dengan tutorial online UT pada perguruan tinggi lain diantaranya akan dipaparkan dalam beberapa paragraf sebagai berikut:

a Materi

Sebagaimana yang telah disebutkan diatas bahwa materi dan aktifitas pembelajaran pada Tutorial Online UT sudah diatur secara seragam antara satu kelas dengan kelas lainnya, berbeda dengan itu, pada PJJ di PIP seluruh aktifitas dan materi merupakan tanggung jawab pengajar. Bahkan, topik atau tema yang diajarkan kepada taruna berbeda sesuai dengan preferensi dari masing-masing pengajar. Meskipun terdapat modul atau buku pegangan bagi taruna dan bagi pengajar, namun untuk materi yang ada dalam PJJ tidak ada ketentuan khusus yang wajib diberikan oleh pengajar. Hal ini memicu perbedaan pemahaman pada konten ataupun materi yang dipelajari antara taruna. Selain itu, pemilihan materi juga berpengaruh terhadap ketercapaian tujuan pembelajaran. Tentu saja efeknya adalah perbedaan nilai akhir yang diperoleh oleh taruna. Hal ini dikarenakan penilaian akhir yang diberikan antara satu kelas dengan kelas yang lainnya sama yaitu diberikan langsung oleh kampus dan dinilai oleh pusat. Jika pilihan materi dan sumber belajar yang ada di laman e-learning berbeda-beda, tentunya nilai yang diperoleh juga memiliki gap yang berbeda. Selain itu, soal tes uian akhir berupa closed-ended question (pertanyaan tertutup), sehingga kemungkinan untuk memberikan jawaban yang berbeda meskipun memiliki maksud yang sama akan dinilai salah. Hal ini merupakan kendala utama dalam adaptasi model PJJ Tutorial Online UT.

b Partisipasi

Selain materi pembelajaran yang didesain secara mandiri oleh pengajar, partisipasi taruna dalam PJJ ini tidak dapat diukur karena tidak adanya forum diskusi yang diwajibkan untuk diikuti oleh setiap taruna. Jika pada Tutorial Online UT setiap mahasiswa wajib untuk menjawab pertanyaan dan melakukan interaksi pada forum diskusi, e-learning PIP tidak didesain untuk memberikan ruang diskusi antar sesama taruna sehingga akan sulit untuk mengukur tingkat partisipasi taruna. Sebagai gantinya, adanya synchronous virtual meeting dengan menggunakan aplikasi video conference dapat digunakan pengajar untuk menilai taruna mana saja yang aktif 
berpartisipasi dalam setiap proses pembelajaran dan mana yang tidak. Namun, dikarenakan sifatnya sinkronus atau langsung, taruna memiliki kepercayaan diri yang rendah dalam berpartisipasi. Selain itu, taruna yang berada di daerah tertentu mengalami kendala akses yang terbatas yang dapat menghambat mereka mengikuti pembelajaran sinkronus.

c Aplikasi

Kendala yang terakhir adalah fitur yang ada pada laman web yang digunakan pada kedua institusi, Fitur e-learning tentu memiliki keterbatasan untuk mengakomodir segala kebutuhan aktifitas pembelajaran sebagaimana layaknya pembelajaran tatap muka. Salah satunya adalah pengajar tidak bisa berkomunikasi secara langsung oleh taruna atau mahasiswa. Terdapat aplikasi pesan yang dapat digunakan oleh mahasiswa untuk menghubungi dosen/ pengajar. Namun, tidak adanya pemberitahuan yang muncul seperti di media sosial membuat para pengajar hanya kan mengetahui apabila pengajar membuka aplikasi e-learning. Hal ini membuat komunikasi dua arah antar pengajar dan mahasiswa terganggu. Untuk itu, penting untuk menggunakan moda perpesanan lainnya selain fitur yang disajikan dalam laman e-learning seperti WhatsApp atau instan messenger lainnya.

\section{KESIMPULAN}

Pembelajaran Jarak Jauh (PJJ) merupakan pembelajaran alternatif utama yang dapat digunakan oleh institusi penyelenggara pendidikan di masa Pandemi Covid-19. Dikarenakan minimnya kesempatan untuk menyelenggarakan pembelajaran tatap muka (face-to-face) ataupun pembelajaran bauran (blended-learning), maka penting bagi seroang pengajar untuk dapat merumuskan pembelajaran yang baik dan menarik dalam PJJ agar tujuan pembelajaran tercapai dengan optimal. Universitas Terbuka sebagai pionir perguruan tinggi yang menyelenggarakan PJJ telah melaksanakan program ini dengan nama Tutorial Online jauh sebelum adanya Pandemi Covid-19. Karena sudah dilaksanakan bertahun-tahun, tentunya sistem yang digunakan sudah cukup baik karena dilakukan pengembangan setiap tahunnya. Untuk itu, perguruan tinggi di masa Pandemi dapat mengadaptasi sistem PJJ yang ada pada Tutorial Online UT. Adaptasi PJJ ini dapat dilakukan baik pada model pembelajaran maupun perumusan materi dan aktifitas yang diberikan. Dengan adanya adaptasi ini, perguruan tinggi yang belum siap atau masih baru dalam menyelenggarakan PJJ di masa Pandemi, dapat melangsungkan proses PJJ dengan baik dan memberikan manfaat yang lebih kepada pengajar dan mahasiswa selaku pengguna akhir dalam pelaksanaan PJJ. Akhirnya, tujuan pembelajaran yang dirumuskan oleh institusi dan dieksekusi oleh pengajar dapat tercapai dengan optimal 


\section{DAFTAR PUSTAKA}

Abidin, Zainal, Hudaya, Adeng, \& Anjani, Dinda. (2020). Efektivitas pembelajaran jarak jauh pada masa pandemi covid-19. Research and Development Journal of Education, 1(1), 131-146.

Astini, Ni Komang Suni. (2020). Pemanfaatan teknologi informasi dalam pembelajaran tingkat sekolah dasar pada masa pandemi covid-19. Lampuhyang, 11(2), 13-25.

Ellyvon Prianata. (2020). Diumumkan Awal Maret, Ahli: Virus Corona Masuk Indonesia dari Januari. Retrieved from https://www.kompas.com/sains/read/2020/05/11/130600623/di umumkan-awal-maret-ahli--virus-corona-masuk-indonesia-dari-januari

Herliandry, Luh Devi, Nurhasanah, Nurhasanah, Suban, Maria Enjelina, \& Kuswanto, Heru. (2020). Pembelajaran pada masa pandemi covid-19. JTP-Jurnal Teknologi Pendidikan, 22(1), 65-70.

ILMAR, D. R. AMINUDDIN, \& SH, M. H. (2020). MEMAHAMI KEBIJAKAN PEMERINTAH: Dalam Menangani COVID-19. Phinatama Media.

Jawahir Gustav Rizal. (2020). Pandemi Covid-19, Apa Saja Dampak pada Sektor Ketenagakerjaan Indonesia. Retrieved from https://www.kompas.com/tren/read/2020/0 8/11/102500165/pandemi-covid-19-apa-saja-dampak-pada-sektor-ketenagakerjaanindonesia

Moleong, Lexy J. (2007). Metode penelitian kualitatif. Bandung: Remaja Rosdakarya

Rahmat, Azka Bazil Danish, Seminar, Kudang Boro, \& Suroso, Arif Imam. (2019). Evaluasi Keberhasilan E-Learning Dalam Perspektif Sistem Informasi (Studi Kasus Universitas Terbuka). Jurnal Aplikasi Bisnis Dan Manajemen (JABM), 5(3), 373.

(C) 2020 by the authors. Submitted for possible open access publication under the terms and conditions of the Creative Commons Attribution (CC BY $\mathrm{SA})$ license (https://creativecommons.org/licenses/by-sa/4.0/) 